\title{
Situating Social Imaginaries in Transitional Justice: The Bushingantahe in Burundi
}

\author{
Bert Ingelaere* and Dominik Kohlhagen $^{\dagger}$
}

\begin{abstract}
$^{1}$
The use of customary institutions and mechanisms is increasingly presented as a solution to operational problems of justice in general and transitional justice in particular. Based on historical research and several months of fieldwork in rural Burundi between 2007 and 2010, this article argues that both attempts, mainly by the Burundian government, to sideline the 'traditional' bashingantahe councils as day-to-day mediators and potentially important actors in the transitional justice process, and strategies, mainly used by international donors and organizations, to rehabilitate and modernize the institution, are obscuring the issue at stake. A shift in focus from the bashingantahe as an institution to the bushingantahe as an organizing principle of social existence is needed. Forms of social imaginaries such as the bushingantahe should be taken into account as sources and outcomes of (transitional) justice.
\end{abstract}

\section{Introduction}

Burundi is experiencing a period of fragile peace in which the question arises of how to deal with the violent past. The Central African country has known a decade of civil war and a history marked by episodes of intense violence since its independence in 1962. During initial peace talks, which resulted in a peace agreement in 2000, the value of the bashingantahe councils as a traditional mechanism of conflict resolution was recognized. ${ }^{2}$ As a result of UN Security Council Resolution 1606 of June 2005, the government of Burundi and the UN are undertaking discussions to define further the nature of the transitional justice process in the country. These do not make any reference, however, to the potential role of the bashingantahe councils. In January 2010, the reform of Burundian municipal law completed this evolution, which had been going on for several years.

* Researcher, University of Antwerp, Institute of Development Policy and Management, Belgium. Email: bert.ingelaere@ua.ac.be

$\uparrow$ Researcher, University of Antwerp, Institute of Development Policy and Management, Belgium. Email: kohlhagen@gmx.net

1 The authors would like to thank Filip Reyntjens and Stef Vandeginste, three anonymous reviewers and the editors of IJTJ for their insightful comments. The usual disclaimer applies.

2 The prefixes umu-, $a b a$ - and $u b u$-, used in quotes from other authors in this article, are variants of the prefixes $m u$-, $b a$ - and $b u$-(shingantahe), respectively. 
The traditional bashingantahe notables, whose role as customary conciliators was previously recognized by state law, were permanently excluded from Burundian (municipal) legislation. ${ }^{3}$

This reform and the disappearance of the bashingantahe from the official talks on transitional justice go against the general evolution observed in the recommendations of international organizations in recent years. ${ }^{4}$ Interest in 'traditional justice' and localized processes pervades these recommendations, which increasingly present improvements to the legal status of customary institutions as a solution to operational problems of state justice in general and in the domain of transitional justice in particular. ${ }^{5}$ In Burundi, 'rehabilitation,' modernization and increased institutional recognition of the bashingantahe have been recommended in countless recent studies. ${ }^{6}$

This article aims to find a new perspective for a better understanding of the actual place these customary conceptions of justice occupy in Burundian society. Based on historical research and observations from fieldwork in 2007, 2008 and 2009, we investigate what the organizing principles of justice in Burundi and the popular expectations of transitional justice represent today. We argue that both attempts, mainly by the government, to sideline the bashingantahe as day-to-day mediators and potentially important actors in the transitional justice process, and strategies, mainly used by international donors and organizations, to rehabilitate and modernize the institution to (better) serve these objectives are obscuring the issue at stake. We suggest that instead of a focus on titles, institutions and individuals formally identified as bashingantahe, what matters in reality is investigating the range and the meaning of the fundamental principles of social existence and justice.

3 Law 1/02 (25 January 2010), amending Law 1/016 (20 April 2005).

4 The integration of 'traditional,' 'local' or 'nonstate' justice systems into the legal system of the state has been recommended, amongst many others, by the UN Development Programme (Access to Justice: Practice Note (2004)) and the UK's Department for International Development (Non-State Justice and Security Systems (May 2004)).

5 Eric Stover and Harvey M. Weinstein, My Neighbor, My Enemy: Justice and Community in the Aftermath of Mass Atrocity (Cambridge: Cambridge University Press, 2004); Luc Huyse and Mark Salter, eds., Traditional Justice and Reconciliation after Violent Conflict: Learning from African Experiences (Stockholm: International IDEA, 2008); Laura Arriaza and Naomi Roht-Arriaza, 'Social Reconstruction as a Local Process,' International Journal of Transitional Justice 2(2) (2008): 152-172; Kieran McEvoy, 'Beyond Legalism: Towards a Thicker Understanding of Transitional Justice,' Journal of Law and Society 34(3) (2007): 411-440; Rosalind Shaw and Lars Waldorf, with Pierre Hazan, eds., Localizing Transitional Justice: Interventions and Priorities after Mass Violence (Stanford, CA: Stanford University Press, 2010).

6 Tracy Dexter and Philippe Ntahombaye, The Role of Informal Justice Systems in Fostering the Rule of Law in Post-Conflict Situations: The Case of Burundi (Geneva: Centre for Humanitarian Dialogue, 2005); International Crisis Group, Réfugiés et déplacés au Burundi: Désamorcer la bombe foncière (2003); Prisca Mbura Kamungi, Johnstone Summit Oketch and Chris Huggins, 'Land Access and the Return and Resettlement of IDPs and Refugees in Burundi,' in From the Ground Up: Land Rights, Conflict and Peace in Sub-Saharan Africa, ed. Chris Huggins and Jenny Clover (Pretoria: Institute for Security Studies, 2005); Assumpta Naniwe-Kaburahe, 'The Institution of Bashingantahe in Burundi,' in Huyse and Salter, supra n 5; Philippe Ntahombaye and Zénon Manirakiza, Le rôle des techniques et mécanismes traditionnels dans la résolution pacifique des conflits au Burundi (Bujumbura: UN Educational, Scientific and Cultural Organization,1997). 
The importance of such foundations for the understanding of the living law of a given society has been repeatedly emphasized by legal anthropologists. Law is 'part of a distinctive manner of imagining the real,' embedded in locally specific systems of meaning. ${ }^{7}$ Étienne Le Roy, for instance, in his writings about an intercultural legal theory, underlines the importance of identifying the elements that make up legality, or rather 'juridicity,' as every society has its own unique ways of imagining the phenomenon of law. ${ }^{8}$ On a broader level, this understanding of law entails a conceptual or even paradigmatic shift from mechanisms, institutions or persons (localized or not, tradition-based or not) to something more encompassing: social imaginaries. The social imaginary is the way

people imagine their social existence, how they fit together with others, how things go on between them and their fellows, the expectations that are normally met, and the deeper normative notions and images that underlie these expectations. ${ }^{9}$

We begin the article by situating the bashingantahe councils in the history of Burundi. The bashingantahe, like any institution, have been affected by sociopolitical and judicial changes. These evolutions and especially the interpretations of these evolutions obscure the fact that the underlying principles of the institution have not been much affected. The second part of the article identifies and qualifies - based on extensive fieldwork in rural Burundi - the vectors through which Burundians imagine social existence and conceive of ways to resolve conflict.

Our insights are based on the findings of two large-scale research projects. One project had the objective of understanding the phenomenon of justice in rural Burundi. The other focused on the population's expectations of transitional justice. ${ }^{10}$ The research on justice in rural Burundi started with a six-month pilot phase on two sites, during which the research team immersed itself in daily life, conducted interviews on local conflict (histories) and identified local mechanisms used to mitigate those conflicts. In a second phase, the research team visited the rural first-instance courts of 51 (out of a total of 129) communes, conducted interviews with local judges and analyzed court records and legal statistics. In addition, the team conducted 647 interviews with the local population, mainly in areas remote from the communal courts. ${ }^{11}$ In the research that focused on

7 Clifford Geertz, Local Knowledge: Further Essays in Interpretive Anthropology (London: Fontana Press, 1983), 173.

8 Étienne Le Roy, Le jeu des lois: Une anthropologie 'dynamique' du droit (Paris: LGDJ, 1999).

9 Charles Taylor, Modern Social Imaginaries (Durham, NC: Duke University Press, 2004), 23.

10 The research project on the phenomenon of justice was designed and carried out by Dominik Kohlhagen in collaboration with 17 Burundian research assistants. The transitional justice research was designed and conducted by Bert Ingelaere in collaboration with 11 Burundian research assistants.

11 For the pilot phase, see, Dominik Kohlhagen, Le tribunal face au terrain: Les problèmes d'exécution des jugements au Mugamba dans une perspective juridique et anthropologique (Bujumbura: RCN Justice et Démocratie, 2008). Quantitative data collected during the second phase can be found in Dominik Kohlhagen, Statistiques judiciaires burundaises (Bujumbura: RCN Justice et Démocratie, 2009). The final results, combining quantitative and qualitative data, have been published in 
expectations of transitional justice, we adopted the following principles and research strategies: (1) establishing variance in the sites for in-depth study (multisited); (2) understanding the breadth and depth of processes; and (3) combining quantitative and qualitative research strategies (mixed method). In total, the team contacted 625 respondents throughout the country through a range of research instruments, while part of the findings is based on observations of the organization of daily life and popular practices in rural communities. ${ }^{12}$

\section{Evolution of the Bashingantahe as an Institution}

The bashingantahe occupied fundamental nodes in the sociopolitical order of precolonial Burundi. They played an important role in conflict resolution at the local level, with the aim of guaranteeing peace, order and harmony. ${ }^{13}$ The bashingantahe were local notables with judicial, moral and political authority. Since they were part of a social order that made no distinction between the judicial, political and social spheres, they embodied justice, knowledge, virtue and authority. According to Thomas Laely, they were 'more justices of the peace than judges of a court.' 14

Under Belgian colonial rule, the 'indigenous jurisdictions' established in 1917 relied extensively on the bashingantahe, although the colonial administration reserved control over their judgments. Practices that were deemed incompatible with the ideals of 'civilization' were simply banned. ${ }^{15}$ At the same time, the social order in which the bashingantahe played several roles gradually disintegrated, and the colonial power instituted administrative authorities that took over tasks normally done by the bashingantahe. ${ }^{16}$

The bashingantahe's incorporation by the state became even stronger after independence. The nomination of the bashingantahe now came under the control of the (single) political party in power, which did not take account of the necessary phases in the traditional investiture process. Evidently, the bashingantahe invested in such a way did not embody the same ideals of virtue and exemplary behavior as those invested by traditional means. The bashingantahe sometimes ended up

Dominik Kohlhagen, Burundi: La justice en milieu rural (Bujumbura: RCN Justice et Démocratie, 2009).

12 Key informant interviews, archival research, (participant) observation, life history interviews, subjective rankings and individual interviews were techniques used during fieldwork as well. More information on study design, methodology and fieldwork can be found in Bert Ingelaere, Living Together Again: The Expectation of Transitional Justice in Burundi-A View from Below (Antwerp: Institute of Development Policy and Management, 2009).

13 Thomas Laely, 'Le destin du Bushingantahe: Transformations d'une structure locale d'autorité au Burundi,' Genève-Afrique 2(30) (1992): 75-98; René Lemarchand and David Martin, Selective Genocide in Burundi (London: Minority Rights Group, 1974).

14 Laely, supra n 13 at 78. All translations of excerpts from texts originally written in languages other than English are by the authors.

15 Administration report of 1921, quoted in Joseph Gahama, Le Burundi sous administration belge: La période du mandat 1919-1939 (Paris: Karthala, 1983). Also see, Laely, supra n 13.

16 Thomas Laely, 'Peasants, Local Communities and Central Power in Burundi,' Journal of Modern African Studies 35(4) (1997): 695-716. 
being described not as customary institutions but as informers of the state security.' ${ }^{17}$

In 1972 and 1988, Burundi experienced two large-scale episodes of violence. In 1972, a Hutu uprising took place in the southern part of the country. In response, the Tutsi-dominated government orchestrated a campaign of so-called 'purification' targeting all Hutu intellectuals and their families. ${ }^{18}$ There was never any 'transitional justice' policy to deal with these events. On the contrary, for about 15 years, it was forbidden to talk about or refer to them. In 1988, another series of massacres occurred in two northern municipalities.

At the end of the 1980s, the question of national unity and reconciliation finally started to be addressed by the government. Developments of the bashingantahe as an institution mainly took place through these discussions at the national level. Several government reports referred to the institution of bashingantahe and/or the values underlying the institution as a factor of unity in the history of Burundi and a pillar of social peace in need of revalorization. ${ }^{19}$

In 1993, Burundi organized presidential elections. The winner, Melchior Ndadaye, was not only the first elected president of Burundi but also the first Hutu president. His presidency lasted just a couple of months. He and other high-level politicians were killed by Tutsi elements in the army on 21 October 1993. The news of the president's assassination resulted in the killings of thousands of Tutsi civilians throughout the country. Retaliation by the army against Hutu civilians followed. This was also the start of a civil war that lasted almost 15 years.

After a military coup in 1996, the government's renewed attention to the bashingantahe institution entered a second phase. A presidential decree 'reinvented' the institution in 1997, with the most visible consequence being the establishment of a consultative national council composed of 40 bashingantahe appointed by the president. This council made several recommendations in the context of the ongoing negotiations between the warring parties at the time. The 'Bashingantahe council for national unity and reconciliation' was also recognized by the transitional constitution of June 1998. The Arusha Peace Agreement, signed in 2000, reiterates this idea of a national 'institution.'

Despite the continuation of political instability after the signing of the peace agreement, several international donors and aid agencies contributed to the so-called 'rehabilitation' of the bashingantahe institution. A vast campaign to

17 Filip Reyntjens, 'L'ingénierie de l'unité nationale: Quelques singularités de la constitution burundaise de 1992,' Politique Africaine 47 (1992): 144.

18 This government-organized and -supervised campaign is labeled a 'selective genocide' or 'forgotten genocide' by some observers (Lemarchand and Martin, supra n 13). For a discussion of the 1972 'events,' see also, Jean-Pierre Chrétien and Jean-François Dupaquier, Burundi 1972: Au bord des génocides (Paris: Karthala, 2007). The killings of Tutsi in 1993 are also labeled genocide by some.

19 Commission Nationale Chargée d'Etudier la Question de l'Unité Nationale, Rapport de la Commission Nationale Chargée d'Etudier la Question de l'Unité Nationale (1989); Commission Constitutionnelle, Rapport sur la démocratisation des institutions et de la vie politique au Burundie (Bujumbura: Régie des Productions Pédagogiques, 1991); Burundian constitution of 1992. 
identify the 'real' bashingantahe was organized throughout the country. Financed by the UN Development Programme, it brought together numerous local and international bodies in a collective effort. ${ }^{20}$ They found precisely 30,411 'traditionally' invested bashingantahe. ${ }^{21}$ The undertaking resulted in the creation of a new National Council of the Bashingantahe in 2002.

The investiture of the bashingantahe at the national level was not able to counter the specter of the politicization of the institution - quite the contrary. Rapidly, the campaign came to be criticized for having privileged certain categories of individuals, in particular those belonging to the urban intellectual elite. ${ }^{22}$

One of the consequences of this controversy is the eclipse of the bashingantahe in the official transitional justice policy (debate). Initially laid down in the Arusha Peace Agreement, the question of transitional justice was only picked up in $2004 .^{23}$ The objective is to install a Truth and Reconciliation Commission and a Special Tribunal within the Burundian judiciary, with the aim of promoting a balanced mix of truth, reconciliation and accountability. Negotiations on transitional justice were called off in 2007. Contrary to the peace agreement, these negotiations made no reference to the bashingantahe whatsoever. ${ }^{24}$

The rather hostile relationship between the party in power, the National Council for the Defense of Democracy - National Forces for the Defense of Democracy (Conseil National pour la Défense de la Démocratie - Forces pour la Défense de la Démocratie, or CNDD-FDD), ${ }^{25}$ and the National Council of the Bashingantahe is one of the factors that contribute to the polemics surrounding the potential role of the bashingantahe as councils. To some extent, these resentments go along the lines of historic divides. While many influential civil society organizations and the National Council of the Bashingantahe are mainly dominated by urban Tutsi elites, the CNDD-FDD counts most of its supporters among the rural Hutu population. A divergent vision of the nature and objectives of the transitional justice process contributes to this problematic relationship, with CNDD-FDD, the former rebel movement, mainly

20 UN Development Programme Project BDI/99/003, 'Appui à la bonne gouvernance, réhabilitation de l'institution des bashingantahe,' and Project BDI/02/B01, 'Appui à la réhabilitation de l'institution des bashingantahe.'

21 Pierre Weiss, Charles Ntampaka and Rose Nzobambona, Rapport de la mission indépendante d'évaluation du projet 'appui à la rehabilitation de l'institution d'Ubushingantahe' BDI/02/B01 (Bujumbura: Schlumberger, 2003).

22 Christine Deslaurier, 'Le “Bushingantahe” peut-il réconcilier le Burundi?' Politique Africaine 92 (2003): 76-96.

23 An excellent history and analysis of transitional justice in Burundi can be found in Stef Vandeginste, Stones Left Unturned: Law and Transitional Justice in Burundi (Antwerp: Intersentia, 2010).

24 UN Security Council, letter dated 11 March 2005 from the Secretary-General addressed to the President of the Security Council, S/2005/158, 11 March 2005. The letter is generally referred to as the 'Kalomoho report.'

25 Before coming to power, the CNDD-FDD was the most significant rebel group active in the civil war. 
emphasizing the need for pardon ${ }^{26}$ and the council adopting a pro-accountability approach. $^{27}$

It is against this backdrop that the ousting of bashingantahe from the legislative process started. A law on judicial procedures, passed in 2005, formally put an end to the role of the bashingantahe as an institution auxiliary to the courts of law. ${ }^{28}$ The municipal law, which also came into effect in 2005, created 'hill and neighborhood councils' elected by universal suffrage that were put in charge of 'ensuring, on the hill or in the neighborhood, together with the bashingantahe of the [administrative] unit, the arbitration, mediation, conciliation and settlement of local conflicts. ${ }^{29}$ The members of the locally elected hill councils are predominantly associated with the CNDD-FDD, while the bashingantahe continue to bear the stamp of their incorporation into the machinery of the former one-party state. The new rulers both at the national and local level, therefore, initially questioned the legitimacy of the bashingantahe. ${ }^{30}$

Our fieldwork made clear that this conflictual situation normalized over time. Although people usually make a clear distinction between the bashingantahe and the elected hill councilors, in most places, both now sit together to deal with local conflicts. In addition, although the revision of the municipal law in 2010 officially put an end to the role of the bashingantahe as local mediators and conciliators, they are still being invested all over Burundi and intervene in most family and neighborhood conflicts.

\section{Organizing Principles of Justice and Social Existence in Burundi}

Despite their exclusion from the national legal system and the historical changes they have undergone, the bashingantahe still play a fundamental role in social cohesion and conflict mitigation. Many recent studies on proximity justice in Burundi rightly emphasize the importance of the bashingantahe in the settlement of day-to-day conflicts. ${ }^{31}$

When a conflict arises between neighbors or when a dispute cannot be solved within a family, people usually seek advice immediately from one of the invested

26 See, CNDD-FDD, 'Memorandum du Parti CNDD-FDD sur la commission vérité et réconciliation et le tribunal special pour le Burundi' (5 May 2007).

27 See, National Council of the Bashingantahe, Mise sur pied de la commission 'vérité et réconciliation' et du tribunal spécial au Burundi: Propositions du Conseil National des Bashingantahe/sages traditionels (2006), on file with authors.

28 Law 1/08 (17 March 2005), providing for the organization and powers of the judiciary.

29 Article 37 of Law 1/016 (20 April 2005), providing for the organization of municipal administration.

30 According to Peter Uvin, the current government even created deliberate confusion by referring to the members of the hill councils as 'elected bashingantahe.' Peter Uvin, Life after Violence: A People's Story of Burundi (London: Zed Books, 2009), 63.

31 RCN Justice et Démocratie, La justice de proximité au Burundi: Réalités et perspectives (2006); Observatoire de l'Action Gouvernementale, Analyse critique du fonctionnement de la justice de proximité au Burundi (2007). 
bashingantahe on their hill. Depending on the urgency of the case, this mushingantahe will convene a meeting of the council on a specified day and time at an outdoor public place. During the meeting, the bashingantahe sit together on the ground or on a bench facing the parties in dispute. Each of them carries a ficus stick (or a ficus stick is passed among them), the so-called intahe, with which he hits the ground every time he speaks. This ritual renders the pronounced discourse very solemn. ${ }^{32}$ Quite frequently, the bashingantahe express themselves through proverbs and call for conciliation and mutual understanding. In some cases, they also adjudicate in favor of one of the parties in the conflict. Their decision is usually unanimous. The session always closes with an invitation to have a beer together, which is issued by the party who asked the bashingantahe to intervene. Traditionally, the (millet or sorghum) beer is served in a gourd from which both parties and the bashingantahe drink through straws. These different rituals are usually understood as essential elements of the reconciliation process.

On most of the hills in Burundi, however, simply holding the title of an invested mushingantahe no longer suffices to ensure the approval of the whole population. In many situations we observed during our fieldwork, conflicts could not be contained effectively by the invested notables and their decisions were contested before the local courts. In some places, the bashingantahe were accused of being biased or even corrupt. ${ }^{33}$

Even though public esteem for these once prestigious dignitaries has declined, the traditional principles of settling conflicts are not fundamentally questioned. This clearly shows in the practice, common in numerous areas, of distinguishing the 'real' bashingantahe from the 'false' ones, and the 'old' ones (invested in the era of the monarchy) from the 'new' ones. ${ }^{34}$ Even though the 'good' and the 'bad' bashingantahe interact when decisions are made, the instinct to identify individuals really worthy of representing the principles of social existence is noticeable in the narratives of the population, which reveals their attachment to traditional values.

Even in areas where traditionally no invested notables were present, Burundians would observe one another and recognize those who seemed worthy of being turned to in case of a conflict. In the event of a disagreement between colleagues in a workplace, a dispute in a public place or a conflict between neighbors, everywhere in Burundi, councils of notables take shape and are reinvented, and this often happens without the explicit mention of the term mushingantahe.

The fieldwork we conducted between 2007 and 2010 revealed that these principles continue to occupy an important place in social interactions. They determine to a great extent the expectations people have of one another and of

32 Interestingly, when the elected hill councilors sit together with the bashingantahe, they usually do not hit the intahe stick.

33 Ingelaere, supra n 12; Kohlhagen, Burundi: La justice en milieu rural, supra n 11; Uvin, supra n 30.

34 See, for example, the 'urgent appeal to the "real bashingantahe." Grégoire Birihanyuma, 'Point de vue: Appel urgent aux "vrais bashingantahe”!' Burundi News, 17 June 2010, http://burundi. news.free.fr/actualites/appelbashingatahe.html (accessed 31 October 2011). 
institutions for administering justice and settling conflicts. In fact, during one of these stays in the field, a conflict between our survey team and the staff of the hotel where we were staying was resolved thanks to the intervention of a small assembly of wise men, which arose spontaneously. We narrate the episode as an example of this informal process.

One afternoon, Eliane, a member of the survey team, saw Aloys, the hotel cook, entering the room where the team kept its money. ${ }^{35}$ When she noticed that money was missing, Aloys had already left the room and he denied having taken anything. Fearing she might be accused herself, Eliane replaced the stolen money with cash from her own pocket and decided to talk to some other members of the team about how she might proceed against Aloys. Quite surprisingly, neither Eliane nor any other member of the team went to see the director of the hotel, the lead researcher or the local police. They went straight to Claver, an old peasant living nearby who was in charge of bringing wood and lighting the fire in the hotel's fireplace every evening. At that moment, they did not even know that Claver was an invested mushingantahe in his community, but somehow they felt that he conformed to the ideal, through his behavior, his speech and his attitudes.

The same day, Claver organized a meeting with some people he chose from among the hotel staff. Weeks later, when the survey team told the story to the lead researcher, they referred to these people as the 'bashingantahe of the hotel,' although none of them had ever been invested as such. The whole meeting was spontaneous and informal, and the assembly did not use an intahe stick. Aloys, however, was probably sufficiently impressed to confess. He told the assembly of an urgent financial problem in his family that led him to steal, and he agreed to pay back a part of the amount. The rest was made up by the research team and some other employees of the hotel. All those involved agreed that, this way, the problem could be considered resolved.

Whether among colleagues, among groups of people from the same neighborhood or among merchants in a public marketplace, Burundians know and recognize, often tacitly, the exemplary individuals to whom they can turn in case of a conflict. To understand this phenomenon, a shift in focus is needed from bashingantahe to bushingantahe.

There is general confusion in the literature about the distinction between the notions of bushingantahe and bashingantahe. Some authors refer to the bushingantahe as an institution and the bashingantahe as the members or representatives of the institution. Others refer to the 'institution of the bashingantahe' as such. ${ }^{36}$

35 All proper names used in examples from fieldwork have been altered to ensure confidentiality.

36 On members or representatives of the institution, see, Christine Deslaurier, 'Le bushingantahe au Burundi: De l'institution locale au patrimoine institutionnel national,' in Le retour des rois: Les autorités traditionnelles et l'état en Afrique contemporaine, ed. Claude-Hélène Perrot and François-Xavier Fauvelle-Aymar (Paris: Karthala, 2003); Laely, supra n 13. On the 'institution of the bashingantahe' as such, see, Philippe Ntahombaye, 'The Rehabilitation of the Bashingantahe Institution: Aims and Issues of the Study,' in The Bashingantahe Institution in Burundi: A Pluridisciplinary Study, ed. Philippe Ntahombaye, Adrien Ntabona, Joseph Gahama and Liboire Kagabo (Bujumbura: Presses Lavigerie, 1999); Dexter and Ntahombaye, supra n 6; Naniwe-Kaburahe, supra n 6; Uvin, supra n 30. 
We define the bashingantahe (councils) as an institution. We use the term mushingantahe to refer to the individual as a member of the bashingantahe. Importantly, we define bushingantahe as the organizing principle of social existence, as an essential form of the social imaginary. ${ }^{37}$

Attempts to translate the term bushingantahe raise a great deal of difficulty. According to historian Christine Deslaurier,

It is difficult to find an appropriate translation for the term bushingantahe, which spans all of the moral, cultural, social and legal dimensions of this institution that lacks any real equivalent, not even in neighboring countries. ${ }^{38}$

French legal anthropologist Charles de Lespinay mentions bushingantahe as an example of a legal term 'for which it is ... impossible to find a translation in simple terms or using the French legal language, as we are unfamiliar with [this concept] in our culture. ${ }^{39}$

The bushingantahe, insufficiently explored in most of the literature on the bashingantahe, makes up the foundation of the institution by designating the values embodied by the traditionally invested bashingantahe. On the whole, the bushingantahe refers to an ideal, a set of virtues, constituting a social reference to righteousness, socialness, sagacity, self-control, responsibility, honor, discretion, equity, truthfulness, coherence and balance in speech, moral and economic independence and prosperity. ${ }^{40}$ The bashingantahe are the men who embody the bushingantahe virtues and promote these values in the community. ${ }^{41}$ Traditionally, only a man judged to be living up to these standards could be invested as a mushingantahe. He would have to show enormous respect for socially recognized values, have good oratory skills and be relatively well off in the material sense.

37 The notion of the social imaginary is closely related to what Pierre Bourdieu calls habitus. Charles Taylor explicitly makes this link in his 'Two Theories of Modernity,' in Alternative Modernities, ed. Dilip Parameshwar Gaonkar (Durham, NC: Duke University Press, 2001). In a previous article, we used a similar argument with respect to the bushingantahe as that developed here, but with reference to the habitus: Dominik Kohlhagen, 'Le bushingantahe au Burundi: Transformations et réminiscences d'un concept judiciaire ancien,' in Cahier d'anthropologie du droit 2009: Dire le droit, rendre la justice (Paris: Karthala, 2010). It is important to note that a social imaginary is commonly 'not expressed in theoretical terms, but is carried in images, stories, and legends,' which is one reason the notion of bushingantahe defies attempts at a final conceptualization. Taylor, supra $\mathrm{n} 9$ at 23 , mentions that the social imaginary 'can never be adequately expressed in the form of explicit doctrines because of its unlimited and indefinite nature.'

38

39 Charles de Lespinay, 'Droits de l'oralité africaine et traduction francophone, un compromis difficile,' Droit et Cultures 44 (2002): 58.

40 Some authors add other values such as 'compassion,' 'hospitality,' 'justice,' 'social cohesion,' 'faithfulness,' 'transparency' and 'tolerance,' although it is questionable whether these notions are part of the semantic field covered by the 'traditional' notion of bushingantahe. This might be the result of attempts, primarily in consultancy reports and documents prepared for the consumption of donors, to translate bushingantahe into western concepts such as 'good governance' or 'the rule of law.' Likewise, values that do not fit into these concepts, like balance in speech or economic independence, are usually not mentioned in these studies. See, for example, Zénon Manirakiza, 'La justice transitionnelle pour la paix sociale: Le système bashingantahe au Burundi' (2007), http://www.constitutionnet.org/files/Bashngantahe.pdf (accessed 31 October 2011).

41 For the position of women as bashingantahe, see, Naniwe-Kaburahe, supra n 6. 
The bushingantahe is embodied by personalities whose reputation commands widespread social acceptance, as the narrative of Claver dealing with the theft of money illustrates. Even though the selection of a new mushingantahe is basically in the hands of already invested notables, historically, his definitive acceptance as a social reference - was usually unanimous. Even at a very young age, a potential mushingantahe had to be able to convince everyone around him by showing that he had 'swallowed,' or internalized, the virtues of the bushingantahe. ${ }^{42}$

In actual practice, as a set of principles, the bushingantahe remains omnipresent. The bushingantahe principles are transposed in various contexts, sometimes in surprising ways, as demonstrated by Claver. Even in the popular appraisal of today's courts, the idea of 'values' usually prevails over the idea of 'legal' or 'normative' order. During our interviews with people involved in litigation, very few rated the magistrates according to their legal competence. Terms like 'norm' or 'law' (itegeko) were usually not even associated with the ideas of justice, peace or equity, but rather with the ideas of constraint, arbitrariness or political power (ubutegetsi, umukuru). When asked to give an example of a 'law,' many people spontaneously referred to obligatory community works or the need to pay taxes. When asked about the competences of a good judge, however, people usually referred to moral integrity, presence or the ability to make people respect his decisions. ${ }^{43}$ Thus, interestingly, many people measure the accomplishments of the national courts using criteria that are reminiscent of the bushingantahe principles of social existence.

Some authors refer to the bushingantahe as a 'philosophy of life, ${ }^{44}$ as a 'state of mind' or as having to do with 'spirit. ${ }^{\text {,4 }}$ The legitimacy of the bushingantahe is not based on its formal institutionalization, but on the values and the 'spirit' it embodies. The quality of those administering justice prevails over the normative content - a fundamental difference from European-inspired law, where it is traditionally the norm that determines the action of the judge.

Observations made during our fieldwork reveal that it is often in the moments most unexpected to a foreign jurist that judges meet the expectations of the population: by calming nerves while the area of contention is being investigated, talking with the parties, explaining again and at length the grounds for a judgment and so on. Usually, people who go to court in Burundi look much more at the behavior of individual judges than at legal procedures. In several interviews, people underlined that they prefer judges who accept an invitation to go for a beer after a trial, as if they expected judges to reproduce the conciliation rituals of

42 Joseph Gahama, 'Origin and Evolution of the Bashingantahe Institution,' in The Bashingantahe Institution in Burundi: A Pluridisciplinary Study, ed. Philippe Ntahombaye, Adrien Ntabona, Joseph Gahama and Liboire Kagabo (Bujumbura: Presses Lavigerie, 1999), 26.

43 Kohlhagen, Burundi: La justice en milieu rural, supra n 11.

44 Agnes Nindorera, Ubushingantahe as a Base for Political Transformation in Burundi (Boston: Boston Consortium on Gender, Security, and Human Rights, 2003), 15.

45 On 'state of mind,' see, Zénon Manirakiza, 'Modes traditionnels de règlement des conflits: l'Institution d'ubushingantahe,' Au Coeur de l'Afrique 1-2 (2002): 39-58. On 'spirit,' see, Ntahombaye, supra n 36 . 
the bashingantahe. In addition, more than 90 percent of interviewees would refuse to have a case judged by a single judge, which reflects the importance of the group aspect in the traditional decision making of the bashingantahe. ${ }^{46}$

The judges most respected by the population are those who cleverly link the position of power that state law confers on them with qualities and attitudes that enable them to be seen as moral references. It is here that the bushingantahe functions as an essential ingredient of the social imaginary and operates as a 'common understanding that makes possible common practices and a widely shared sense of legitimacy. ${ }^{47}$ As emphasized by Peter Uvin, institutions in Burundi are very generally measured by the qualities of the individuals they contain. When there is a demand for improvement, terms like 'better people' are used, rather than 'better structures. ${ }^{48}$

\section{Bushingantahe as a Source and Outcome of Transitional Justice}

Mechanisms and objectives derived from the global transitional justice paradigm are scheduled to be implemented in Burundi. This paradigm has recently taken a turn toward localization and traditionalization of processes, meant to adapt transitional justice processes to local circumstances. ${ }^{49}$ The idea of using the bashingantahe as an 'indigenous' source in Burundi's transitional justice process perfectly fits this trend. ${ }^{50}$

The bashingantahe institution has, at first sight, the potential to serve as such a source. For example, our fieldwork indicates that the bashingantahe are indeed considered a source of peace and social cohesion at the local level, as stipulated in the Arusha Peace Agreement. ${ }^{51}$ In the countryside, we did not observe the dominance of a specific ethnicity in the composition of the councils. This does not confirm what politicized debates, often along ethnic lines, in the capital, Bujumbura, might suggest. Both Hutu and Tutsi are invested as mushingantahe in the interior of Burundi. We also did not observe any ethnic prejudice in the actual proceedings at the local level. Moreover, a significant number of bashingantahe played an important role in tempering and preventing ethnic violence on the hills. ${ }^{52}$ However, although the bashingantahe as an institution has a certain degree of legitimacy at the local level, the differences in appreciation according to

46 Kohlhagen, Burundi: La justice en milieu rural, supra n 11.

47 Taylor, supra $\mathrm{n} 9$ at 23.

48 Uvin, supra n 30 at 66.

49 See references, supra n 5 .

50 See references, supra n 6.

51 Ingelaere, supra n 12.

52 See, for example, narratives collected in Ingelaere, ibid., which also show, on the other hand, that some (invested) bashingantahe participated in the violence themselves or in incitement to violence and repression. See also, Philippe Ntahombaye, Traditional Institutions for Peaceful Resolution of Conflicts: The Role of the Bashingantahe During the 1993 Crisis in Burundi (Burundi: Life and Peace Institute and University of Burundi, 2003). 
ethnic identity suggest that the politicization of the institution continues to have an influence. ${ }^{53}$ In any case, undertaking judicial proceedings to identify guilt and responsibility in connection with large-scale crimes or establishing the truth about what happened in the past is considered to be beyond the abilities and competence of the bashingantahe.

In fact, our analysis of popular expectations of the transitional justice process shows that holding perpetrators accountable and establishing the truth is often not desired, irrespective of the mechanism. Among those who are in favor of the use of a Truth and Reconciliation Commission and a Special Tribunal, expectations of how the mechanisms will function are often formulated in a particular fashion. The following excerpt from a group discussion with inhabitants of a hill in the central province of Gitega provides testimony of the popular way of thinking about dealing with the past and the mechanisms envisioned for Burundi.

Q: What expression can be used to express your preferences regarding dealing with the problems of the past here?

(1) I think that nothing should be forgotten given what has happened here ... $(3,4)$ [We disagree.] 'One does not have to dig up what has been buried' (nta kuzura akaboze), one must move forward and leave aside what happened in the past and in fact, peace will come. (5) Even if one unearthed the stone, ${ }^{54}$ it would not return our loved ones [who were killed], therefore, 'nta kuzura akaboze.' (1) I think that those who played an instigating role [during the violence] must take the lead by confessing, there are some of them who even spoke on radio [to incite people to violence], the Burundians must dig up this stone themselves.

\section{Q: What do you think of the Truth and Reconciliation Commission?}

(1) We often hear talk about this commission, its role will be to seek the truth. (2) This commission will be installed to help us, but it is we ourselves that firstly need to have in mind the spirit of reconciliation. Two brothers who are in conflict may not agree without a mediator. One can forgive someone who has sinned when that person asks for forgiveness. When one asks for pardon, pardon is granted. (3) No one is against this commission! We need to reconcile. (1) It must be that this commission organizes meetings with all segments of Burundian society [Hutu, Tutsi, Twa, repatriated, released prisoners and internally displaced persons]. We will find an agreement on the final report and the solution will be found by everyone in this country.

\section{Q: What do you think of the Special Tribunal for Burundi?}

(5) That the tribunal comes and starts investigations from the beginning of the conflict until today. (4) I am against the tribunal. For me, it would be digging up what has been buried (kuzura akaboze). (2) It is true, a tribunal is necessary because without it, nothing is possible. This tribunal will seek causes and when it is necessary to punish, well, let's punish. (1) The tribunal is not necessary. What is important is the dialogue.

53 Ingelaere, supra n 12.

54 Referring to the expression, 'the stone unearthed will not damage your hoe anymore' (ibuye ryaserutse ntiryica isuka). This expression suggests that dealing with the violence of the past could prevent future violence. The stone is the symbol of negative experiences (violence and killings). 
Dialogue alone will be the source of a solution to our problems. If you asked someone who killed, he responds that it is because President Ndadaye was killed, but for him, he does not know why the president was killed. Whether for the Hutu or the Tutsi, dialogue is more important than this court. (2) [Regarding dialogue,] the bashingantahe can help! When there is a conflict between a Hutu and a Tutsi, a mushingantahe, without any distinction, should be impartial. They advocate reconciliation. (4) They help a lot! They do not distinguish according to ethnicity during a trial. ${ }^{55}$

As this exchange shows, no outright consensus has emerged on transitional justice within Burundi. An awareness exists that some process needs to be initiated to facilitate living together again, as well as that high-level politicians and military leaders need to account for past crimes, but the people we consulted often preferred the option of leaving the past behind by 'not digging up what has been buried' (nta kuzura akaboze). They argued that it is better to leave what happened in the past and what has been left untouched for a long period, or at least to not bring 'bad experiences' into the open, as this might have negative consequences. This insight is corroborated by the findings of other large-scale research projects. ${ }^{56}$

The first reason for Burundians' reluctance to venture into a transitional justice process is a general awareness that virtually everybody has been a victim of violence in the past and that many share responsibility for violent incidents. Another reason for the reluctance to participate in prosecutions and truth-telling initiatives is that dealing with the past and achieving transitional justice objectives will be very difficult in Burundi, mainly due to insecurity caused by ongoing rebel activity.

A third reason - and the most important with respect to our focus here - is related to the fact that inhabitants of rural Burundi use a different epistemological framework to formulate their reflections on what is labeled 'transitional justice. ${ }^{57}$ They deploy practices other than the typical transitional justice activities (denunciation, accusation, prosecution, truth telling and compensation) and stress objectives other than the typical transitional justice objectives (accountability, truth, reparation and reconciliation). At times they use other expressions and concepts to refer to similar objectives. It is not simply a matter of forgetting the past; it is a

55 Focus group discussion, Gitega Province, Commune Itaba, Burundi, 26 February 2009: (1) peasant, male, Hutu, aged 28; (2) peasant, male, Hutu, aged 49; (3) peasant, female, Hutu, aged 28; (4) peasant, female, Hutu, aged 59; (5) peasant, female, Hutu, aged 56.

56 Cyrus Samii, 'Who Wants to Forgive and Forget? Civilian Attitudes toward Post-Conflict Justice and Truth in Burundi,' Working Paper (New York: Columbia University, 2009); Ann Nee and Peter Uvin, 'Silence and Dialogue: Burundians' Alternatives to Transitional Justice,' in Shaw and Waldorf, with Hazan, supra $\mathrm{n}$ 5. The report presenting the findings of a national consultation on transitional justice mechanisms suggests, however, that the Burundian population is very much in favor of the envisioned transitional justice process. Les Consultations Nationales sur la Mise en Place des Mécanismes du Justice de Transition au Burundi, Rapport (April 2010). There are several methodological problems with this consultation, mainly the fact that no fundamental questions were asked, such as whether people are in favor of a transitional justice process and what kind of process. The population could mainly voice its opinions on technical issues regarding the implementation of the mechanisms already scheduled to be implemented.

57 For a similar observation regarding the transitional justice process in Rwanda, see, Bert Ingelaere, 'The Gacaca Courts in Rwanda,' in Huyse and Salter, supra n 5. 
matter of dealing with the past differently. In the exchange above, the discussion spontaneously shifts to the notion of dialogue, which is different from truth telling, and almost automatically evokes what a mushingantahe is and does. Dealing with the violence of the past and preventing its recurrence in the future is threaded into the web of tightly knit face-to-face communities, which is difficult to understand from the perspective of an outsider who is used to different preconceived categories of what is taken for granted. Again, to understand this phenomenon, a shift in focus is needed from bashingantahe to bushingantahe. Bushingantahe as a principle of social existence is both source and outcome, inspiration and aspiration, when ordinary Burundians formulate their expectations regarding dealing with a violent past.

First, the bushingantahe as a key characteristic of the social imaginary shapes the implicit grasp of social space. ${ }^{58}$ During discussions on how to deal with the past and live together again, a revitalization of daily life and interactions is tacitly stressed. Dialogue, speech, reconciliation, festivities, ceremonies, reunions and regroupings are notions that are often repeated. ${ }^{59}$ Peasant narratives, like those quoted below, reveal an expectation that the social fabric will be strengthened, a wish to come together and a need to place everything where it used to be before everything fell apart.

[We need to] organize festivities hill by hill, and Hutu and Tutsi can enter into dialogue and reinforce the social cohesion. ${ }^{60}$

[We need to] create associations where all 'groups' come together and enter into dialogue. ${ }^{61}$

We should create ceremonies where beer would be offered and shared with former neighbors. $^{62}$

Our fieldwork showed that people primarily expect the bashingantahe - also as opposed to other institutions - to bring reconciliation and communal ritual activities such as 'coming together,' 'reintegrating people in society,' 'honoring victims' and 'dialogue. ${ }^{63}$ The participants in our research demonstrated a desire to open spaces of togetherness, to recreate sociability. One has to keep in mind that bushingantahe means the fact of planting (gushinga) the intahe stick. The intahe root in the notions bashingantahe and bushingantahe refers to bringing 'form and substance to ideals of fairness and morality in society. ${ }^{64}$ Planting the

58 Taylor, supra $\mathrm{n} 9$ at 26.

59 One has to keep in mind that the notion of Ijambo, or speech or discourse, is attached to the popular understanding of the qualities of a mushingantahe.

60 Personal interview, peasant, male, Hutu, aged 52, Kayanza Province, Burundi, 10 May 2008.

61 Personal interview, peasant, male, Hutu, released 'political' prisoner, aged 46, Kirundo Province, Burundi, 26 March 2008.

62 Personal interview, peasant, female, Tutsi, ex-internally displaced person, aged 62, Gitega Province, Burundi, 10 March 2008.

63 Ingelaere, supra n 12.

64 John M. Janzen and Reinhild Kauenhover Janzen, Do I Still Have a Life? Voices from the Aftermath of War in Rwanda and Burundi (Lawrence, KS: University of Kansas, 2000), 221. 
intahe means to bind, reconstitute and reconcile. Intahe primarily has the connotation of 'what determines where things belong. ${ }^{\text {'65 }}$

Second, by taking into account the bushingantahe as an essential form of the social imaginary, one understands that social control is especially exercised through 'diffuse sanctions': the fear of being marginalized or, simply, being considered ridiculous. The legitimacy of the bashingantahe comes from them being the 'designated and authorized reproducers of the moral imaginary of society. ${ }^{66}$ In 2007, a group of older male respondents in northern Burundi was asked what had to be done with perpetrators of low-level disorder living in their communities. The men unanimously answered that such behavior is considered to be characteristic of 'outsiders to the community' and that these people are 'morally condemned. ${ }^{, 67}$ A moral condemnation is not physical or social exclusion, but it is a form of accountability when translated into the language in vogue in transitional justice. In his doctoral thesis, Laely expresses a similar observation by affirming that, in Burundi, 'social control was not produced by sanction but by the interiorization of the norm. ${ }^{68}$

Third, dealing with the past from the perspective of an ordinary Burundian peasant for the large majority seems to mean the facilitation of 'a change of heart.' During many of our conversations throughout the country, it was stated that the heart (umutima) has changed because of the crimes committed, the violence experienced or the dehumanizing acts observed.

(1) People don't live in harmony anymore, there is discord and the economic situation is bad. (2) People's hearts have changed, we have witnessed a lot of events. (3) For instance, we who were young, we were traumatized by what we saw. (2) There are Tutsi who are traumatized because of what they've been through. ${ }^{69}$

Umutima is the force that unifies the human being. Although the 'western' notion of 'heart' is already rich in meaning (hence the reason for umutima generally being translated as 'heart'), it does not fully capture the multitude of connotations of umutima. Emotions, will and reason are captured by the word umutima without distinction. ${ }^{70}$ Umutima is that which distinguishes men (umuntu) from beasts

65 Naniwe-Kaburahe, supra n 6 at 154. See also, Joseph Bigirumwami, 'Uses of the Word Intahe and Its Corollaries in the Burundian Language and Culture,' in The Bashingantahe Institution in Burundi: A Pluridisciplinary Study, ed. Philippe Ntahombaye, Adrien Ntabona, Joseph Gahama and Liboire Kagabo (Bujumbura: Presses Lavigerie, 1999).

66 Julien Nimubona, Analyse des représentations du pouvoir politique: Le cas du Burundi (Lille: Atelier National de Reproduction des Thèses, 1998), 286.

67 Fieldwork observations, Marangara commune, Burundi, March 2007.

68 Thomas Laely, Autorität und Staat in Burundi (Berlin: Dietrich Reimer Verlag, 1995), 173.

69 Focus group discussion, Gitega Province, Commune Itaba, Burundi, 12 April 2008: (1) peasant, male, Hutu, aged 70; (2) peasant, male, Hutu, aged 40; (3) peasant, male, Hutu, aged 30.

70 For a discussion of umutima in the context of the sociocultural universe of Rwanda, a society similar to Burundi, see, Dominique Nothomb, Un humanisme africain: Valeurs et pierres d'attente (Brussels: Lumen Vitae, 1965); Pierre Crepeau, Parole et sagesse: Valeurs sociales dans les proverbes du Rwanda (Tervuren: Musée Royal de l'Afrique Centrale, 1985). 
(inyamwaswa). It also has the connotation of spirit (but not the western concept of 'soul'). ${ }^{71}$ Laely refers to umutima when discussing the personal virtues needed to become an invested mushingantahe, as both imply essentially the same virtues. ${ }^{72}$ This shows the importance of 'ways of being' and the desire to change 'ways of being' as a response to past violence in Burundian society. Ancient Burundian law clearly valorizes 'ways of being,' noting 'ubushingantahe is a condition, not a position. ${ }^{, 73}$

Fourth and last, many people not only expect others to behave according to the bushingantahe but also want to live up to this ideal 'inside themselves.' This is another reason bushingantahe should be considered both a valuable source in the shaping of the transitional justice process and a desired outcome. The social imaginary as an implicit understanding of how things normally are or go is interwoven with an idea of how they ought to go. ${ }^{.74}$ In the human sphere, gradations exist with respect to the nature of umutima one aspires to or possesses. Someone with umutima mwiza is a highly esteemed person both morally and socially - 'noble from the heart.' During our stay on a hill in Southern Province, close to the town of Rumonge, many respondents spontaneously evoked the name of one of the inhabitants - André, a father of 10 - as such an exemplary person.

In 1997, at the height of the civil war, this hill was repeatedly attacked by Hutu rebels, who focused their violence mainly on the civilian population. As a result of general ethnic polarization in the war, these attacks pitted the inhabitants against each other along ethnic lines. The rebels and the government army waged a war by proxy: civilians were either targeted or incited to attack their neighbors. As André remembers,

One day, it was April, rebels attacked all Tutsi households and also some Hutu households. That day they burned my house. It was around $8 \mathrm{pm}$. We were able to save ourselves, but the house and all my belongings were burned. Everything inside my house was ravaged by the fire: six bags of beans, 10 bags of rice, televisions, clothes ... I saved only my life. I lost property with a value of 21,000,000 Burundian francs. After that attack, some stupid soldiers came to me and said I had to avenge myself [against the local Hutu population]. I explained to them that one should not take revenge on people who had nothing to do with the people that had burned my house. ${ }^{75}$

André refused to give in to the desire for vengeance, to lose his humanity and become beast-like (inyamwasa). Instead, he repeatedly organized gatherings to maintain unity on the hill and security patrols in which both Hutu and Tutsi

71 As we have mentioned, the bushingantahe has the connotation of 'spirit.' Nindorera, supra n 44; Ntahombaye, supra n 36.

72 Laely, supra n 13.

73 Ntahombaye and Manirakiza, supra n 6 at 4.

74 Taylor, supra $\mathrm{n} 9$ at 24.

75 Personal interview, peasant, male, Tutsi, aged 57, Bururi Province, Commune Rumonge, Burundi, 27 April 2008. 
participated. The local inhabitants have not forgotten how André behaved during this period. As one inhabitant explained,

[In that period of upheaval] we had good leaders, they maintained calm within the population; people came to take refuge here [at the church]. There was a certain André [who acted that way], God bless him. ${ }^{76}$

It is important to note that André is an invested mushingantahe, part of the local bashingantahe council. In his neighborhood, however, he is not admired because of his invested position but because of what he did and therefore who he is. Other invested bashingantahe did not act with such 'humanity' and are therefore not highly esteemed, despite their official status. People tacitly know who are the good and bad bashingantahe, irrespective of investiture. André has become a source of inspiration to others, especially as he was in a position of power during the conflict as a chef de zone (administrator of a zone within a commune). People admire and aspire to the 'ways of being' of others who behave in accordance with the values associated with the institution of bashingantahe, especially of those who have power over them. ${ }^{77}$

\section{Conclusion}

While in most studies the bashingantahe are said to be an 'institution,' a 'traditional authority' or individuals who decree norms, this portrayal is an incomplete one. The real foundation of the institution resides in a set of social representations. It is this specificity that Julien Nimubona summarizes when he writes that

the label of bushingantahe is not so much meant for a physical person, but rather for an anthropological and sociological concept. It evokes not only a belief in the superiority and the transcendence of social values, but also an object (the mushingantahe) and a custom (the function of embodying certain values or settling conflicts and giving advice in the name of wisdom). ${ }^{78}$

Although the bashingantahe as an institution have a degree of legitimacy at the local level, people tend to make a tacit distinction between the set of values commonly referred to as bushingantahe and the people who become the representatives of these values over the years, the invested bashingantahe. This becomes apparent during observations of justice practices and discussions on how to deal with the violence of the past. Ordinary Burundians primarily emphasize the need to adopt a specific discursive and largely nonprosecutorial approach that will 'open a space to come together again' in order to explore and revitalize shared practices and aspirations of 'ways of being.' From an outsider perspective, one could say they stress objectives other than globally accepted transitional justice objectives, but an insider point of view reveals that the two sets of objectives may

76 Personal interview, trader, male, Hutu, aged 40, Bururi Province, Commune Rumonge, Burundi, 23 April 2008.

77 Uvin, supra n 30.

78 Nimubona, supra n 66 at 282. 
be similar but are formulated and pursued in a different fashion, with the Burundians focusing on a way informed by the omnipresent bushingantahe principles of social existence.

What is clear is that the rehabilitation of bushingantahe not as an 'institution' but as a principle within the judiciary and the transitional justice process could live up to the expectations of Burundians. The nature of bushingantahe means, however, that there is no clear procedure for supporting or operationalizing such an undertaking. What is primarily needed is an 'awareness' of this essential ingredient in the local social imaginary in both the conception and assessment of sociolegal and transitional justice interventions, especially since transitional justice is dominated by 'legalism. ${ }^{79}$ A specifically designed commission - like the Truth and Reconciliation Commission - complemented by an institution that establishes some sort of accountability at some point in time - like the Special Tribunal - will have to be part of this process because Burundi is obligated to establish them by Protocol 1 of Article 8 of the Arusha Peace Agreement. Two options are thus available: compromise or complementarity.

With compromise, dealing with the past can be done differently, even through globally accepted mechanisms. What is important is that the transitional justice practices imported from abroad are imbued with the endogenous principles of bushingantahe. This could occur, for example, by accepting discourse - talking as a way of truth telling; by using moral condemnation as a form of accountability; by judges or commissioners being chosen primarily based on their moral authority instead of their legal competence; and by understanding that the sharing of food and drink will be paramount to achieving reconciliation in any aspect of the transitional justice process and in any operationalization of a transitional justice mechanism.

With the complementarity option, imported transitional justice mechanisms would be designed according to the globally accepted transitional justice norms, but they would operate at the macro level of Burundian society and thus at a significant distance from the local population. The objective would be primarily to hold a small number of high-level instigators of violence accountable and, through a truth commission, to clarify the history of Burundi. At the same time, and most important, at least as much effort, energy and resources - and preferably even more - would need to be invested in nonjudicial and grassroots initiatives inspired by the bushingantahe principles of social existence. Creative thinking would be needed to design programs and projects with objectives in line with the popular expectations discussed in this article. Although, judged from the outside, these initiatives might not be considered part of a typical transitional justice process, for Burundians they would be essential ingredients in the process of dealing with the past and living together again.

With respect to the invested bashingantahe, the choice to ban them from the national legal system and to avoid reference to them during the transitional justice

McEvoy, supra n 5. 
debates may do them more good than harm. Considering the political controversy within Burundian society and the overall problems with formalizing customary institutions in transitional justice processes as such, it is in any case better not to scale them up to some mechanism that fits the exogenous transitional justice model. Such an operation would cause, at best, friction, which does not have to be negative, or, at worst, short circuits that would be harmful to the entire process. ${ }^{80}$ If the bashingantahe are left outside the formal intervention, they might end up playing a role anyway as a spontaneous resource solicited by the people.

Importantly, the Burundian case reveals that the turn in the global transitional justice paradigm toward decentralized, localized or place-based initiatives or processes should be accompanied by more attention to something that has been a blind spot until now. Very few studies that stress the importance of localizing transitional justice by focusing on spontaneous and informal initiatives or 'indigenous' mechanisms have also attempted to map their underlying principles systematically. ${ }^{81}$ As with the bushingantahe in Burundi, these essential forms of social imaginary should be taken into account as sources and outcomes of (transitional) justice.

80 Rosalind Shaw, 'Memory Frictions: Localizing the Truth and Reconciliation Commission in Sierra Leone,' International Journal of Transitional Justice 1(2) (2007): 183-207; Bert Ingelaere, “'Does the Truth Pass across the Fire without Burning?" Locating the Short Circuit in Rwanda's Gacaca Courts,' Journal of Modern African Studies 47(4) (2009): 507-528.

81 Writing on Guatemala, however, Lieselotte Viaene emphasizes the need to take into account the 'internal logic of the cosmos,' meaning the indigenous epistemology or belief systems, among the Maya Q'eqchi' Indians to understand their way of dealing with a violent past. Lieselotte Viaene, "The Internal Logic of the Cosmos as "Justice" and "Reconciliation": Micro-level Perceptions in Post-Conflict Guatemala,' Critique of Anthropology 30(3) (2010): 287-312. 